DOI: $10.1515 /$ hssr -2016-0017

\title{
Religiosity versus Spirituality in the Contemporary Nigerian Gospel Music
}

Floribert Patrick Calvain Endong*

University of Calabar, Nigeria

\begin{abstract}
There have been remarkable ( $\mathrm{r}$ )evolutions in the Nigerian gospel music industry for the past decades. These revolutions have led to the emergence and survival of various modern and controversial musical cultures/traditions, modes and performances including worldliness and paganism in the industry. In view of these relatively nefarious musical cultures, a good number of scholars and observers tend to arguably redefine and (re)brand Christian communication in general and Nigerian gospel music in particular. It is in following this premise that this paper examines the phenomenon of religiosity and worldliness in the Nigerian gospel music industry. Based on observations and secondary data (literary sources), the paper argues that the Nigerian gospel music industry is just a vivid reflection of the country's gloomy socio-religious landscape, characterized by the emergence/prevalence of fake ministers and various ubiquitous instrumentalities that perpetrate spiritual bareness in the country. Aspects of religiosity observed in some Nigerian gospel songs include controversial rhythms, imitations/adaptations of worldly songs, lyrical emphasis on prosperity (materialism, fame and earthly glories) at the detriment of spirituality/salvation, gospel artists being associated with sex scandals and occult practices.
\end{abstract}

Keywords

Nigerian Gospel Music, Religiosity, Spirituality, Divine Theory of Music, Christian Alternative Music.

* Department of Theatre and Media Studies, University of Calabar, P. M. B. 1115, Calabar, Cross River State, Calabar-Nigeria; floribertendong@yahoo.com 


\section{Introduction}

Defining religious communication often hinges on three essential factors, namely the religious convictions/orientations of the author (sender), the themes (lyrical content) and the spiritual purpose of the communication. In line with this, Christian music is construed as a category of musical artistry produced (exclusively) by practicing Christians, invested with Christian themes/messages and seriously impacting the spiritual being of audiences. Corroborating this assertion, Ajiri remarks that gospel music is a timeless genre which pays special tribute to God and contains powerful messages of worship and praises that reach to the very depths of audiences' souls, touching every aspect of their beings (Ajiri, 2013: 1). In addition to the three factors mentioned above, some critics also identify form (instrumentation) as another vital parameter to consider in defining Christian music. In tandem with this, Robin asserts that, just like lyrics are endowed with a great formative power, aesthetical ingredients such as melody, harmony and rhythm (in gospel music making) are far from being spiritually and morally neutral. This is very much in accordance with Aristotelian and Platonic views on music. In his words, "music [melody, harmony and rhythm] can affect the ordering of the soul in ways that are either conducive to human flourishing or which contribute to our disordering" (Robin, 2015: 6).

However, anchoring the definition of Christian music on more or less generic, arguable and elusive concepts such as Christian and spirituality, is somewhat problematic. In effect, there factually (and regrettably) exist multiple categories of Christians (notably nominal and practicing/true). Also, the concept of spirituality is immensely abstract and humanly immeasurable as a variable. As Love rightly observes, "spirituality is a concept whose definition is a bit more diffuse and with less agreement regarding its meaning" (Love, 2014: 6). And without any desire to exaggerate, one may say that only a very gifted person will concretely capture or detect spirituality in a piece of communication so-categorized as Christian. As the Bible succinctly puts it, spiritual phenomena (thus elements of spirituality) are spiritually known and discerned (1 Corinthians 1: 14-15). The Bible equally reminds us that not all those who say "Lord", "Lord" (those who claim or pretend to be godly) are actually sincere and approved of God (Matthew 7: 21-32) ${ }^{1}$. By extension/analogy, not all the musicians or songs which explicitly profess complete and boundless loyalty to Jesus are actually 
genuine and spiritual. There therefore, somehow arises the need to differentiate simple religious (Christian) music - which merely represents an emotional or economic experience - from spiritual music, which is a divinely provoked experience and an evangelical/salvific movement. A producer of Gospel rap (FDD) quoted in Servant stresses the imperativeness to make such a distinction when he notes that:

[Gospel] music is good and evil. Why is it good and evil? Because Lucifer was playing music in heaven before God sent him down. And God asked somebody else to play music for him. So, [...] we should watch out, because the Bible said he comes, steals and destroys. The devil is looking for whom to seek and defy. $\mathrm{He}$ is coming through music, because music penetrates more than anything. (Servant, 2003: 67)

In the same line of argument, critics such as Gordon (2014) and Robin (2015) insightfully contend that through fake(d) gospel music, paganism has successfully made inroads into the church. "Though sadly, many Christians no longer believe [gospel] music is an area where we need to exercise discernment. They have fallen prey to a number of music myths perpetuated by the godless philosophy of our day" (Robin, 2015: 33). There is therefore need for greater discernment by Christians so as to sort the genuine spiritual gospel music from mere religious music (or pagan music in disguise). Hinging principally on observations and a critical review of literature, this paper presents a reflection on the two issues of religiosity and spirituality in the Nigerian gospel music. It explores these phenomena and proposes a way of coming to terms with them.

\section{Theoretical Framework}

This paper hinges on two theories, namely the divine theory of music and the inspiration theory. According to the divine theory, music - the same as the other forms of artistic expressions - is divinely inspired. In line with this, the gospel music singer is envisioned as being divinely inspired or possessed. The divine theory of music is reflected in a good number of conceptions shared in the world of music in general, for instance the belief that the word "music" is derived from the muses which were types of demigods possessing the capacity to inspire an artist's musical production. The concept 
of the genius also goes in line with this theory. In effect, an artist's genius is his/her inspiring spirit. A good number of renaissance paintings depict such powers of the muses and the genius.

The inspiration theory likewise states that religious communication, especially the Bible, is inspired by God. In line with this theory, religious music is inspired by God. The inspiration theory however has a multitude of versions which need adequate explanations. The first version presents religious music as being inspired and inspiring in so far as it addresses issues of human life in a profound way. In line with this, gospel music is viewed as inspired in the same sense as any worldly musical composition or performance profoundly anchored on humanistic/humanitarian principles. Another version of the inspiration theory views Christian communication (notably Christian music) as partially inspired. In such a context, part of the communication is inspired while the remaining part may be the product of personal reflections. In line with the partial or limited inspiration version, some gospel music may lyrically be inspired while their instrumentations are the product or the respective artists' reflection. As Bauder (2015) notes, people who hold this theory see Christian communication as inspired and authoritative "when it teaches morality or ethics or salvation", but they insist that it may contain errors when it records secular issues. In practice, the partial or limited inspiration theory "turns out to be a way of dismissing those sections of the Christian communication that an audience or receiver finds uncomfortable. Typically, the inspired parts of the communication are taken to be those portions or aspects that agree with the specific sensibilities of the audience.

A third version of the inspiration theory views Christian communication as being totally inspired by God, but with some parts being more inspired than others. In line with this, communications that directly relay passages of the Bible (especially words of the Lord Jesus Christ and God) are considered more inspired than those recoding spiritual reflections of religious teachers. In line with this, a gospel song with lyrics that reproduce psalms may be considered more inspired than a spiritual musical composition deriving from the personal talent of a Christian artist. 


\section{Conceptual Framework}

Religiosity could simplistically be defined as the state of being religious or too religious. It is manifested by a mere belief in the existence of a god or gods, and implies a high degree of apparent piety (respect for God). According to Love, religion as a phenomenon operates through faith and intuition. It is a concern over what exists beyond the visible world and generally includes the idea of the existence of a particular god (or group of divinities), an eternal principle or transcendental spiritual force that has generated the world, that systematically governs and controls it, that determines its destiny or intervenes occasionally in the natural course of the history of this world (Love, 2014: 2). Religion also includes a specific fundamental set of beliefs and rituals (notably baptism, Holy Communion, prayer in Christianity) arising as a human response to such beliefs in God or eternal principle. Religiosity is manifested in a variety of practices and rituals such as church attendance, prayer, grace before meals, identification with a particular religious denomination, and beliefs in a supreme being. Love notes that "while some of these, it may be argued, relate to rejection of spirituality, most do not address issues of spirituality at all [as] they are merely simple external measures or practices associated with religion" (Love, 2014: 3-4). Love further differentiates between religiosity and spirituality when he notes that:

In so many instances, religions and people acting in the name of some religion have behaved in ways that are antithetical to the notions of genuineness, wholeness, transcendence, and connectedness that are expressed in the definition of spirituality. Human history is stained with the blood of people oppressed, abused, and murdered in the name of some religion, its supreme being, or its doctrines [...] I cannot think of a single religion that does not fall into this category. Christianity, Judaism, Islam, Hinduism have all condoned or otherwise supported barbaric, anti-spiritual actions. It seems to me that this occurs in part when beliefs and practices, which may, in fact, have begun as spiritually grounded exercises, mutate into dogma and doctrines. The dynamic spiritual aspect of the religion of early adherents was lost or repressed. Religion and spirituality became disconnected. (Love, 2014: 4)

Religiosity is believed by most fundamentalist and charismatic Christian sects to be insufficient and irrelevant unless combined with or supplemented 
by holiness and spirituality. This is in accordance with the fact that, in many instances, the Bible censures "empty" religiosity. In James 2: 19-20, the Holy Scriptures state that there is nothing extraordinary and heroic in mere belief in God: "thou believest that there is one God. Thou doest well: the devils also believe and tremble". Similarly in James 1: 26-27, the Bible recommends that religiosity be perfected with holiness (spirituality) thus: "if a man among you seems to be religious and bridleth not his tongue, but deceiveth his own heart, this man's religion is vain. Pure religion and undefiled before God and the Father is this, to visit the fatherless and widows in their affliction and to keep himself unspotted from the world".

In tandem with this, spirituality or holiness indispensably validates religiosity. Love defines spirituality as "an internal process of seeking personal authenticity, genuineness, and wholeness as an aspect of identity development" (Love, 2014: 5). The Bible differentiates the spiritual from the carnal (animal) man. It presents a spiritual person as one entirely filled with and guided by the Holy Spirit and as someone acting in an irreproachable manner (1 Corinthians 2:12-16). Contrarily to the spiritual man, the carnal or simply religious - person has a great predisposition to sin, as he does not receive the things of God or does not possess the Spirit (Power) of God. Love replicates this idea in the distinction he makes between genuine and false/illusory spirituality.

[The acts of] meditating in unusual physical positions, communing with nature, seeking conversation with the spirit world, etc., may seem to be "spiritual," but they are in fact false spirituality. True spirituality is possessing the Holy Spirit of God as a result of receiving salvation through Jesus Christ. True spirituality is the fruit that the Holy Spirit produces in a person's life: love, joy, peace, patience, kindness, goodness, faithfulness, gentleness, and self-control $[\ldots]$ Spirituality is all about becoming more like God, who is spirit [...] and having our character conformed to His image. (Love, 2014: 5)

In line with this, spiritual music is principally associated with divine inspiration and the power of the Holy Spirit (Colossians 3:16); mere religious music (being a consequence and manifestation of carnality) may have Christian themes but it lacks divine energy to connect both the singer and the audiences to God and facilitate the spiritual intercourse between the two parties. 


\section{Worldliness and the Secularization of World Christian Music}

Early Christian attitudes towards gospel music were mostly conservative, rigorous, relatively extremist and purposely spiritual. Christian music was, in this respect, principally viewed as a means of worshiping God in an original way. It was construed as an activity which is diametrically concurrent to secular or pagan musical artistry. In effect, such conceptions stemmed from the fact that there was a real demarcation between Christianity and paganism as well as between the sacred and the secular (Robin, 2015: 4; Cloud, 2014: 15; Stouffer, 2012: 4; Lauritsen, 2011: 13; Olsen, 1996: 5). In line with this, Durkheim assumed a clear separation between the sacred and the secular, considering these two words to refer to two "separate worlds" since, as he strongly argued, "religious and profane life cannot coexist in the same place" (Durkheim, 2008: 39-40). In the context of Christian music making, such a rigid demarcation was considered to be cutting across not just the lyrics (texts composition) but equally the rhythm as well as gospel music performance. Based on this conception, specific musical traditions - such as rap, rock and roll, hard rock and the like - were easily branded the music of the devil and thus, perceived to be extremely hostile to the Christian faith. Some of this negative labeling rested on arguable stereotypes. Noebel David cited in Joseph (1999), for instance, bases his judgment of Christian rock and roll and similar "aggressive" rhythms on such stereotypes (popular conceptions of "impure" rhythm makers), as he notes that Rock musicians are most often "pro-drugs, pro-evolution, pro-promiscuous sex; anti-Christ and more [...] Rock music is a negation of soul, spirit, and mind, and is destructive to the body [...] It's also been shown that rock music destroys house plants. If it destroys God's plants, what's it doing to young people?" (Joseph, 1999: 35). Similarly, and with close reference to gospel music making in Nigeria, FDD in Servant frowns at a variety of rhythms arguably considered secular. He particularly warns Christian musicians and audiences against Gansta Rap, R\&B, and Makossa, remarking that:

Gangsta rap will never favor you. Gasta rap is of the devil and I want to tell you as a man of God, that you must be born again, you must free yourself from it, you must free yourself from ganstarism. The devil is trying to take you off. God loves you, so you better change from gansta and do something for God. 
$[\ldots]$ so, you should know that the music you are doing $[\ldots]$ is good or evil and there is some music, all this Makossa ${ }^{2}$, it is terrible. We should watch out, because the Bible said he comes, steals and destroys. [...] He is coming through music, because music penetrates more than anything, so all those dancing Makossa, opening their legs and other things, they are evil. They are just terribly evil. Music shouldn't be a thing that corrupts us. (Cited in Servant, 2003: 65 - 67)

Serious sensitivity to the nature - and perceived/imaginary purity - of rhythm has motivated most early gospel music singers to explore and endorse visibly modest musical traditions such as country music, soft rock and ballads. In line with this, there has been a remarkable move towards encouraging the praise through hymnody. However, over the years, Christian artists have progressively designed methods of shaping their musical productions to the taste of a modern and mostly worldly audience. In Nigeria, this paradigm shift has been manifested by the incorporation of hitherto "impure" and contentious music traditions into traditional Christian worship and gospel music. Servant (2003) observes this fact as he notes that most Nigerian churches today "resonate to more worrying sermons. They moralize on public behavior, watch over daily activities with an iron fist and shatter traditional taboos. The sermons are often accompanied by rappers or Makossa musicians openly devoted to the Pentecostal churches" (Servant, 2003: 55). The paradigm shift (in favor of worldliness and the secularization of gospel music) partially has its root in Christian artists and audiences' inferiority complex. Such a complex made them (the musicians) see traditional gospel music not as sufficiently lucrative, competitive and suitable enough to be aired in secular radio and television stations or performed in off-church forums such as concerts. In line with this, Olsen insightfully notes that "retailers and radio stations avoided contemporary Christian music initially" as they hardly considered it an industry-accepted category, deserving radio airplay on Christian and secular stations (Olsen, 1996: 17). Similarly, Lauritsen mentions such a complex of inferiority on the part of Christian artists when he stresses the secularization process of the Christian music.

This process started out slowly. While there were bands here and there that were fully Christian in orientation, none were mainstream or popular enough to gain any attention, let alone revenue. Mainstream culture did not want to hear 
Christian music played on the radio because it was "too preachy" and Christian radio listeners did not like Christian music on the radio because it was going "too far". The popularity of Christian music happened somewhat accidentally with the injection of the word "Jesus" into popular, otherwise secular, songs. (Lauritsen, 2011: 15)

Therefore, secularity and worldliness in gospel music making and performance partially stemmed from (post-)modernist, liberalist and capitalistic currents, specifically the desire to shape production in a way that will appeal to a dominantly worldly market. Gospel music was not to be regarded solely as an art of worship but a fertile and lucrative activity, a plausible way for the religious artist to win his bread. Capitalistic and modernist tendencies have actually caused gospel music to progressively become a site of creativity and inventiveness. Such creativity is translated by multiple forms of secularization of the genre among which must be mentioned the "Christian alternative music" movement. Olsen (1996) succinctly describes this movement as the "arty, but unheralded stepchild of contemporary Christian music", a genre which is "too holy for the world" and conversely "too worldly for the Church". He compares Christian alternative music with (genuine) contemporary gospel music thus:

Christian alternative artists as a group have focused on innovative music and imaginative song lyrics, rather than words and harmonies now familiar in contemporary Christian music. While most contemporary Christian artists strive to be evangelistic, alternative artists show a greater willingness to experiment artistically as well as to compose songs about the dark side of life. (Olsen, 1996: 6)

The secularization has equally been noted in the performance of the genre (for instance in concerts), with the visible secularization of everything within the space in which contemporary Christian music is being performed. Such an approach is arguably necessary and fruitful as it functions "as a way to define the social space for those who observe it. In this way this space is removed from that of a church and is now a setting for a secular activity but with a sacred message" (Lauritsen, 2011:13). The dominant tendency in the industry worldwide has therefore been the combination of perceived sacred messages with worldly performance tradition. Worldly Christian music has 
HSS, vol. V, no. 2 (2016): 133-144

thus emerged as a kind of hybrid genre aiming at merging virtual opposites: the holy and the pagan, the sacred and the impure and so on. These factors and more have sufficed to push Gordon to predict the imminent decline of contemporary Christian music ${ }^{3}$.

\section{Religiosity in the Contemporary Nigerian Gospel Music}

Religiosity in the Nigerian gospel music is created or intensified by a number of irreligious and arguable myths. Some of these myths elevate every church attendant or sympathizer to the rank of a Christian while others celebrate the belief that a musical composition is Christian (in nature) so long as it has Christian themes. This is not unconnected to the fact that the Nigerian nation has most often been described as being very religious in nature (Endong, 2015: 5; Ezeh, 2014: 14; Ekanem and Bassey, 2009: 11; Okon, 2008: 76; Offiong, 2005: 106-107; Amadi, 2005: 38; Maduka, 2003: 17; Servant 2003: 66). Indeed, it is a society where anyone will likely identify himself or herself as Christian, irrespective of his or her real spiritual life, that is irrespective of whether he/she is just a nominal or practicing Christian. A number of observers, scholars, anthropologists and sociologists have thus seriously marveled at the high degree of religiosity in the Nigerian society which ironically is virtually not matched with a proportional level of spirituality. Oputa cited in Servant insightfully remarks that religion - and, by extension, gospel music - in the Nigerian socio- religious ecology is simply a lucrative business and nothing else.

The new wave of Pentecostal churches that are sweeping the whole place [are] only playing on hopelessness and helpless people. I can understand why most Nigerians are sucked into that kind of bullshit [...] Most of these people who are creating all these churches and even congregations, from the way I see it, they don't even come close to being good Christians. You have so many churches here and so much evil all around you, people are doing some real evil things in the name of religion, so yes it is a business for those people who want to capitalize on the poverty, the frustration and the hopelessness of the Nigerians. (Servant, 2003: 64)

In line with this, gospel music has become just a business and an art or venture open to any musician. Little, nay, no favorable condition is enthusiastically created for spirituality to thrive in the Nigerian gospel music 
industry. Indeed, even purely secular musicians have adopted/usurp the identity of "God sent", "called", "anointed ministers" in the guise of preaching and praising God through gospel music making. Such musicians view themselves circumstantially as Christians, and consider themselves deeply inspired by God, irrespective of the fact that some of their musical compositions and/or performances are in total contradiction to some core Christian values. In his critique of the Nigerian gospel music industry Ezeh (2014) makes such an alarming diagnostic when he opines that "modern Nigerian gospel artists could be anything but godly. In the least, they are controversial, materialistic and unlearned in theology". In effect, thanks to Nigeria's gullibility in the face of religion, most gospel music makers are having a field day. "They are quick to sing about spirituality: love, decency, virtues and God! But you struggle only to find them light miles away from their teachings". Ezeh further contrasts contemporary gospel singers to early Christian artists in terms of sincerity stating that: "in the time past, no gospel artist would admit that he or she has not been called. Especially as the society expects that a gospel artist must have heard and obeyed the call of God to spread the message of Salvation through music. But no. Not today's gospel artists. Not anymore [...] Their intent however may not be unconnected with enriching themselves. Today's gospel artists readily perform anywhere, including clubs. When quizzed, they're quick to remind you that they have to reach as many souls wherever they are".

Religiosity in the Nigerian gospel music is also principally evidenced by artists' visible tendency to immensely copy secular or pagan music in both the modes of composition and performance. Some of the songs are pure adaptations, imitations or remix versions of secular songs. In view of this, one is left to wonder how God will inspire only the lyrics of a song without inspiring the melody. A good number of Nigerian gospel artists have developed the musical culture of competing with worldly pop music makers "in making sounds with such bemusing tags" including gospel pop, hard rock, gospel rap, gospel afro, gospel dancehall. In the guise of indigenizing their musical production, some of these artists have instead resorted to mobilizing instrumentation employed in the performance of traditional religion rituals. All these innovatory musical practices have made Nigeria's contemporary gospel music to be a veritable site of astonishing inventiveness and creativity (Endong, 2015: 6; Ezeh, 2014: 5). This tendency is in line with 
HSS, vol. V, no. 2 (2016): 133-144

such musical myths stating that in Christian music making, only lyrics have the potential of influencing the soul. However Robin (2015) seriously contradicts this myth contending that:

One of the ways Christians routinely misunderstand music is in thinking that only the words can have a formative influence on the soul. The very idea that the unique combination of melody, harmony and rhythm that goes into any piece can contribute to the ordering or disordering of the soul, often strikes us as strange. It is almost an unquestioned axiom that only the words contain spiritual and ontological significance. As such, we've failed to take seriously the warnings of Plato and Aristotle on the formative power of melody, harmony, and rhythm. In this regard, it is we who are strange, for until the twentiethcentury it was universally understood that music [instrumentation] can affect the ordering of the soul in ways that are either conducive to human flourishing or which contribute to our disordering. Until recently, it never even occurred to serious thinkers (whether Christian or pagan) to suggest that apart from lyrics music is a realm of complete spiritual and moral neutrality. (Robin, 2015: 7)

Apart from the relatively questionable or controversial instrumentation they used, a good number of contemporary Nigerian gospel artists anchor the messages of their songs essentially on materialism and other worldly concepts such as fame and earthly glories, so as to principally appeal to the emotions of the masses that are very much interested in motivational discourses and (cheap) consolation. Capitalizing on the poverty, frustration and hopelessness of Nigerian masses, some of these singers specialize in preaching mere prosperity, sometimes at the detriment of spirituality, thereby defeating the ultimate purposes of Christian communication which are evangelic and salvific. This has inspired Etcetera (2014: 34) to describe most Nigerian gospel songs as a simulation of spiritual artistry/activity and spiritually misleading enterprises.

Just like our Nigerian pastors, Nigerian gospel songs cannot lead you to Christ. Nigerian songs are not spiritually uplifting. They are mostly about the things of the flesh, about riches and fame. The simple use of religious terms and phrases here and there is not enough to lead anyone to Christ. I dare you to go to any Nigerian gospel musician's website and see if you will find a simple plan of salvation. You won't. Most of the songs being sold to the public as "Christian songs" are religious rubbish. Most of them are songs 
without the truth, 'Churchianity' and not Christianity. Because most of the Nigerian gospel musicians are themselves not Christ-like. They carry as many babes as the worldly hip hop stars. Fornicate on Saturday night and minister to you in church on Sunday morning, tasking you to wave your handkerchief in the name of the Lord.

As noted by Etcetera above, another aspect of this religiosity in the Nigerian gospel music industry is the fact that a good number of these artists are associated with terrible controversies. The Nigerian gospel music industry is just a reflection (an extension) of the country's present gloomy socio-religious landscape, characterized by the emergence of fake ministers and various and ubiquitous instrumentalities that perpetrate spiritual bareness in the country ${ }^{4}$. Today, it has become common that pastors and gospel artists be involved in sex scandals and occultism (Endong, 2015: 7; Ezeh, 2014: 6; Ukpabio, 2008: 17; Servant, 2003: 88). This aspect of religiosity and worldliness in Nigerian gospel music may be evidenced the more by the fact that a good number of Nigerian gospel musicians have managed to get embroiled in love and sex scandals. Egregious examples are Sammie Okposo and Lanre Teriba who, besides being fingered in alleged illicit romantic affairs, have fathered children out of wedlock. Also to be cited here are popular gospel artists such as Gloria Doyle and Tope Alabi who have gotten orgasm courting controversies. Other gospel singers such as Keefee and Doyle have, in numerous instances, faced acerb criticisms (from the Nigerian public) on their dressing style. Reporting such virulent criticism, The Nigerian Voice (2012: 11) notes that Gloria Doyle is probably "the worst of them all so far. Only in her dress sense has she presented herself as a gospel musician". The online newspaper further explains that: "a few years ago, she was always seen dressed in semi-nude clothing that would have been better imagined than seen. The Nigerian society however rose with one voice to condemn her severely. Gloria wasn't moved though by all the criticisms, defending herself that she had the right to dress as she liked".

Despite such an alarming context (worldliness in Nigerian gospel music industry), many prevalent myths strongly advocate that audiences focus more on the music rather than the spiritual life of musicians (in accordance with the "do as I tell you and not as I do' maxim), totally forgetting that music is generally conceived as a powerful force that has a way of breaking down barriers. "And the same powerful force can be tainted with negative 
lyrics and ungodly lifestyle that can pierce through the hearts of the listeners and reshape their values" (Etcetera 2014: 1). There is therefore an intrinsic and indispensable link between genuine worship or preaching (genuine gospel music making) and character of life (Wayne, 2014: 23). Though Christian audiences presently adopt a careless attitude towards music consumption in general, gospel music still remains an area where strict discernment should be exercised. Hearing (the same as other senses) are doors through which God and Satan pass to find a destination in the human heart, no doubt; Romans 10: 17 states "faith cometh by hearing, and hearing by the word of God". Likewise, corruption and spiritual bareness come by hearing, this time around, by hearing by the words of the world.

\section{Conclusion}

It is obvious that the remarkable (r)evolutions witnessed in the Nigerian gospel music industry have progressively led to the emergence of various modern and controversial musical cultures, modes and performances including worldliness in the industry. The Nigerian gospel music has thus become a site of inventiveness, a fertile ground for worldliness and arguably moral corruption. In view of these modern musical cultures, a good number of scholars and observers tend to arguably redefine and (re)brand Christian communication in general and Nigerian gospel music in particular.

This paper has systematically examined the phenomenon of religiosity and worldliness in the Nigerian gospel music industry based on a well enunciated conceptual framework which sought to define spirituality and religiosity. Principally based on observations and secondary data (literary sources), the paper argued that aspects of religiosity observed in some Nigerian gospel songs include controversial rhythms, imitations/adaptations of worldly songs, lyrical emphasis on prosperity (materialism, fame and earthly glories) at the detriment of spirituality/salvation and gospel artists being associated to sex scandals and occultist practices. In tandem with this, the Nigerian gospel music industry could be viewed as a reflection of the country's present gloomy socio-religious landscape, characterized by the emergence/prevalence of fake ministers and various ubiquitous instrumentalities that perpetrate spiritual bareness in the country.

The phenomenon of religiosity in the Nigerian gospel music has visibly come to stay. Mere religious music making is therefore a culture modern 
HSS, vol. V, no. 2 (2016): 133-144

Christianity will manage to live with. Unfortunately, most Christians in Nigeria nowadays adopt liberal views about music as they seem to have abandoned discerning thinking about Christian music. However, the incursion of paganism in the gospel music very much calls for greater discernment in the area of music consumption.

\section{References}

Ajiri, E. (2013). Impactful Singing. Port Harcourt: A-Jayz Prime Music.

Amadi, E. (2005). Ethics of Nigerian Culture. Ibadan: Heinemann Educational Books.

Ashbaugh, J. E. (2012). "Christian Music Industry and Church Music: The Relationship Between Christian Music Industry and Church Worship Music". http://www.ashbaugh/articles/christian_music_industry_and_church_music.c om Acessed on 27/06/2015.

Bauder, K. T. (2015). "Theories of Inspiration". Religious Affections. http://www.religiousaffections.org/articles/in-the-nick-of-time/theories-ofinspiration. Accessed on 25/06/2015.

Cloud, D. (2014). The Transformational Power of Contemporary Praise Music. Port Huron: Way of Life Literature.

Crowe, B. J. (2010). Music and Soulmaking: Toward a New Theory of Music Therapy: New York: Sacrecrow Press.

Durkheim, E. (2008). The Elementary Forms of Religious Life. New York: Oxford University Press.

Ekanem, S. A. \& Bassey, P. A. (2009). "Religion and Science as Tools of Economic and Social Development". ONIONG: A Contemporary Journal of InterDiscipline Studies, 1(1), 13-27.

Endong, F. P. C. (2015). "Glossolalia in the Nigerian Gospel Music: Aesthetic Feature or Archetype of a Pentecostal Identity?". IJAHS: International Journal of Art and Humanity Sciences, 2(2): 14-20.

Etcetera. (2014). "Nigerian Gospel Artists are Hypocrite". GistMannia, at http://www.gistmannia.com. Accessed on 17/06/2015.

Ezeh, E. (2014). "Opinion: In the name of Gospel Music". http://www.naij.com/67712.html. Accessed on the 16/06/2015.

Frith, S. (1996). Performing Rites: On the V alue of Popular Music. Cambridge: Harvard University Press.

Gordon, D. T. (2014). "The Imminent Decline of Contemporary Worship Music: Eight Reasons". Second Nature Journal.http://www.secondnature.com/the- 
Floribert Patrick Calvain Endong, Religiosity versus Spirituality in the Contemporary ...

HSS, vol. V, no. 2 (2016): 133-144

imminent-decline-of-contemporary-worship-music-eight-reason $/ \mathrm{htm}$.

Accessed on 26/06/2015.

Joseph, M. (1999). The Rock and Roll Rebellion. Nashville, Tennessee: Broadman \& Holman.

Lauritsen, M. W. (2011). "Secular Mode, Sacred Message: How Contemporary Christian Musicians are Called by God to Perform". Sociology Undergraduate Research Paper 2, http://www.repository.stcloudstate.ed/soc_org_research/2 Accessed on 27/06/2015.

Love, M. (2014). "What is the Difference Between Religion and Spirituality?" Gotquestions. http://www.gotquestions.org/religion-spirituality.html\# rxzz3d3eboWFb. Accessed 16/06/2015.

Maduka, C. T.( 2003). "The Clouds are Thickening: Nigerian Languages and Literatures in National Development". JONEL: Journal of Nigerian English and Literature, 4(1): 11-19.

Meyer, B. (2003). "Pentecostalism, Prosperity, and Popular Cinema in Ghana". Representing Religion in World Cinema: Film Making, Mythmaking, Culture Making. New York: Palgrave MacMillan.

Offiong, A. O. (2005). "Video-Films as Mediators of Pentecostal Christianity in Nigeria: A Case Study of Liberty Video-Films". WAACLALS: West African Association for Commonwealth Literature and Language Studies, 2(1), 106-119.

Okon, E. E. (2008). "The Sociological Imagination on Religion”. CASIL: Calabar Studies in Languages, 14(1), 110-138.

Olsen, T. (1996). "Too Holy for the World, Too Worldly for the Church". CT: Christianity Today, 40(11), 12-27.

Robin, V. (2015). "Music: Myths, Meanings, Messages and Mediums". Christian Worldview Journal. http://www.christianworldviewjournal.com/html. Accessed on the 16/06/2015.

Servant, J.-C. (2003). Which way Nigeria? Music under Threat: A Question of Money, Morality, Self-Censorship and the Sharia. Denmark: Freemuse.

Stouffer, G. (2012). Evaluating Music Biblically- A Concise Guide. New York: International Partnership Ministries Inc.

The Holy Bible. (2007). Authorized King James Version. Chicago: Remnant Publications.

The Nigerian Voice. (2012). What Manner of Gospel Artists? TNV, Available at http://www.file:///F:/My\%20Documents/Floribert $\% 27 \mathrm{~s} \% 20$ articles $\% 202 / \mathrm{I}$ $\mathrm{n} \% 20$ Theatre $\% 20$ and $\% 20$ Media/Will $\% 20$ soon $\% 20 \mathrm{be} \% 20$ published/

Appropriation \%20in \%20Gospel\%20Music/WHAT\%20MANNER\%20OF \%20GOSPEL \%20ARTISTS.htm

Ukpabio, H. (2007). Rapture. Oweri/Lagos: Liberty Films. 
HSS, vol. V, no. 2 (2016): 133-144

Ukpabio, H. (2008). The Seat of Satan Exposed. Calabar: Liberty press.

Wayne, J. (2014). "The Divine Pattern of Acceptance Worship". Christian Courier Publication. http://www.christiancourierpublication.com

${ }^{1}$ In this scriptural reference, Jesus Christ says: "Not every one that saith unto me Lord, Lord, shall enter into the kingdom of heaven; he that doeth the will of my Father which is in heaven. Many will say to me in that day, Lord, Lord have we not prophesized in thy name? and in thy name have cast out devils? And in thy name done many wonderful works? And then will I profess unto them, I never knew you: depart from me, ye that work iniquity".

${ }^{2}$ Makossa is originally a traditional rhythm from Cameroon. In Nigeria the term is popularly used to refer to a very suggestive dance style. Makossa as a popular culture is used by many Nigerian secular and even religious musicians.

${ }^{3}$ In his article titled "The Imminent Decline of Contemporary Worship Music", Gordon David enumerates over eight serious threats to the contemporary gospel music industry. They include the paucity of lyrical creativity among gospel artists (compared to early gospel music composers), the over-use of particular hymns of the Christian hymnology and the illegal incorporation of worldly and pagan traditions in the gospel music composition and performance, with institutions such as the Praise Teams (performing in churches) being cardinal vectors of such a perversion of the industry, among other factors.

${ }^{4}$ In her book titled The Seat of Satan Exposed, and her 2007 drama (Rapture), Helen Ukpabio amply describes the gloomy nature of the Nigerian socio-religious ecology, enumerating multiple unholy practices by a number of spiritual leaders and gospel music singers.

\section{Biographical note}

F. P. C. Endong was born in Bouraka, Cameroon, in 1983. He attended the universities of Buea (Cameroon) and Calabar (Nigeria) where he respectively obtained a Bsc in Journalism and Mass Communication in 2008 and a M.A. degree in Media Art Studies (in 2013). He is presently a PhD scholar at the Department of Theatre and Media Studies, University of Calabar, Nigeria. 